\title{
Kallmann syndrome in an adolescent boy
}

\author{
Manisha Jana • Atin Kumar
}

Received: 21 December 2009/Revised: 20 January 2010 /Accepted: 28 January 2010/Published online: 12 March 2010

(C) Springer-Verlag 2010

A 16-year-old boy presented with hypogonadotropic hypogonadism and congenital anosmia. MRI revealed absent olfactory bulbs and sulci and flattened gyri recti (Fig. 1). Diagnosis of Kallmann syndrome was made. An MRI of a normal brain is presented for comparison (Fig. 2) and shows normal olfactory sulci (white arrow) and olfactory bulbs (open arrow).

Hypogonadotropic hypogonadism with associated anosmia or hyposmia is designated Kallmann syndrome. It is

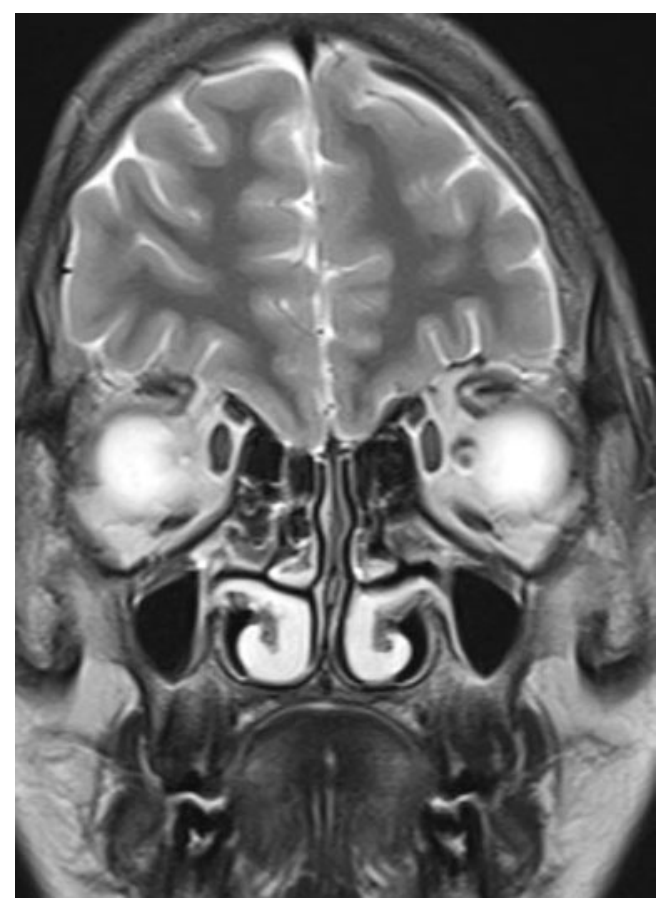

Fig. 1 Coronal T2-W MRI of boy with Kallman Syndrome

M. Jana $(\bowtie) \cdot$ A. Kumar

Department of Radiodiagnosis,

All India Institute of Medical Sciences,

New Delhi, India110029

e-mail: manishajana@gmail.com caused by the absence of olfactory nerves, bulbs and sulci; has $\mathrm{X}$-linked recessive (mutations in KAL1 gene; girls uncommonly affected); and autosomal-dominant inheritance patterns. Associated anomalies include renal agenesis, cardiovascular anomalies, cryptorchidism, short fourth metacarpals and midline craniofacial anomalies. Clinical diagnosis is straightforward in adults but often requires MRI $[1,2]$ and hormonal analysis in pre-pubertal boys.

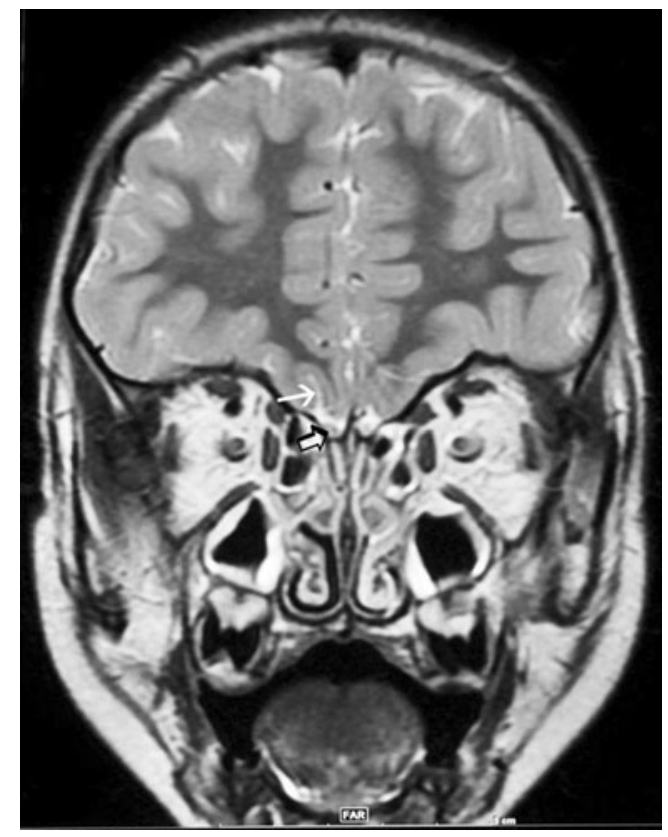

Fig. 2 Coronal T2-W MRI of a normal brain

\section{References}

1. Knorr JR, Ragland RL, Brown RS et al (1993) Kallmann syndrome: MR findings. AJNR 14:845-851

2. Abolmaali ND, Hietschold V, Vogl TJ et al (2002) MR evaluation in patients with isolated anosmia since birth or early childhood. AJNR 23:157-164 